\title{
Penerapan Model Example Non Example untuk Meningkatkan Keterampilan Proses Sains Siswa Sekolah Dasar
}

\author{
Yelira Novita ${ }^{1}$, Putri Hana Pebriana ${ }^{2}$, Astuti $^{3}$ \\ Program Studi Pendidikan Guru Sekolah Dasar, Fakultas IImu Pendidikan \\ Universitas Pahlawan Tuanku Tambusai \\ Email : yeliranovita0196@gmail.com
}

\begin{abstract}
Abstrak
Latar belakang dalam penelitian ini adalah rendahnya keterampilan proses sains pada mata pelajaran IPA di SDN 016 Balung dengan jumlah siswa 11 orang, di buktikan dengan hasil tes tertulis keterampilan proses sains siswa yang rendah. Tujuan penelitian adalah untuk mendapatkan gambaran tentang perencanaan pembelajaran IPA untuk meningkatkan keterampilan proses sains, pelaksanaan pembelajaran IPA untuk meningkatkan keterampilan proses sains, peningkatan keterampilan proses sains dengan menggunakan model pembelajaran Example non Example. Jenis penelitian yang digunakan adalah penelitian tindakan kelas (PTK) yang terdiri empat tahapan dalam setiap siklusnya yaitu perencanaan, pelaksanaan, pengamatan, dan refleksi. Penelitian dilaksanakan sebanyak dua siklus yang setiap siklusnya terdiri dari dua pertemuan. Alat pengumpul data penelitian adalah lembar observasi dan lembar kerja siswa. Teknik analisis data menggunakan teknik analisis kualitatif dan kuantitatif. Hasil penelitian pada siklus I dengan persentase 63,6\% (kategori kurang), siklus II meningkat menjadi 90,9\% (kategori amat baik). Dengan demikian, pembelajaran IPA dengan menerapkan model Example non Example dapat meningkatkan keterampilan proses sains siswa.
\end{abstract}

Kata Kunci : Model Example non Example, Keterampilan proses IPA

\section{PENDAHULUAN}

Perkembangan ilmu pengetahuan dan teknologi semakin pesat. Perkembangan ini memungkinkan semua pihak dapat memperoleh informasi dari berbagai sumber. Dengan demikian siswa perlu memiliki kemampuan memperoleh, memilih, dan mengelola informasi untuk bertahan pada keadaan yang selalu berubah. Salah satu cara untuk mencapai hal tersebut dapat diperoleh melalui pendidikan sekolah.

Sekolah adalah lembaga pendidikan formal yang bertanggung jawab atas pendidikan siswa. Salah satu lembaga pendidikan formal tersebut adalah Sekolah Dasar (SD). SD merupakan jenjang pendidikan yang wajib ditempuh sebagai dasar awal dalam proses peningkatan mutu pendidikan dalam rangka meningkatkan manusia Indonesia seutuhnya yang memiliki daya saing untuk menghadapi tantangan global. Menurut Peraturan Pemerintah Nomor 19 tahun 2005 tentang Standar Nasional 
Pendidikan, Pendidikan Dasar bertujuan untuk meletakkan dasar kecerdasan, pengetahuan, kepribadian, akhlak mulia, serta keterampilan untuk hidup mandiri dan untuk mengikuti pendidikan lebih lanjut.

Pendidikan bertujuan untuk meningkatkan kualitas sumber daya manusia. Selain itu, pendidikan juga dapat membentuk watak serta peradaban bangsa yang bermatabat dalam rangka mencerdaskan kehidupan bangsa, bertujuan untuk berkembangnya potensi siswa dengan adanya belajar.

Salah satu mata pelajaran yang diajarkan di SD yang dapat mengembangkan potensi siswa untuk mengembangkan pribadi manusia seutuhnya, yang berarti menyangkut unsur cipta, rasa dan karsa, ranah kognitif, afektif dan psikomotor adalah mata pelajaran IImu Pengetahuan Alam (IPA). Sebagaimana yang tertera dalam tujuan pembelajaran IPA di SD menurut Mulyasa (2008:111) Kurikulum Tingkat Satuan Pendidikan (KTSP) yaitu:

1. Memperoleh keyakinan terhadap kebesaran Tuhan Yang Maha Esa berdasarkan keberadaan, keindahan dan keteraturan alam ciptaanNya.

2. Mengembangkan pengetahuan dan pemahaman konsep-konsep IPA yang bermanfaat dan dapat diterapkan dalam kehidupan sehari-hari.

3. Mengembangkan rasa ingin tahu, sikap positif dan kesadaran tentang adanya hubungan yang saling mempengaruhi antara IPA, lingkungan, teknologi dan masyarakat.

4. Mengembangkan keterampilan proses untuk menyelidiki alam sekitar, memecahkan masalah dan membuat keputusan.

5. Meningkatkan kesadaran untuk berperan serta dalam memelihara, menjaga dan melestarikan lingkungan alam.

6. Meningkatkan kesadaran untuk menghargai alam dan segala keteraturannya sebagai salah satu ciptaan Tuhan.

7. Memperoleh bekal pengetahuan, konsep dan keterampilan IPA sebagai dasar untuk melanjutkan pendidikan ke SMP/MTs.

Berdasarkan tujuan mata pelajaran IPA di atas salah satu yang dikembangkan adalah keterampilan proses. Oleh karena itu, tujuan pembelajaran IPA di SD hendaknya lebih menekankan pada pemilikan kecakapan proses dibanding dengan penguasaan materi IPA, karena kecakapan proses ini merupakan kecakapan prasyarat yang harus dimiliki siswa agar dapat mempelajari bidang studi lainnya sesuai dengan minatnya (Suderadjat, 2004: 75).

Tujuan pembelajaran IPA tersebut dapat tercapai apabila dalam proses pembelajaran siswa selalu aktif memperoleh pengetahuannya sendiri melalui proses sains. Menurut pendapat Asyari (2006: 22) yang menyatakan bahwa dalam pembelajaran IPA sebaiknya diciptakan kondisi agar siswa selalu aktif untuk ingin tahu sehingga pembelajaran 
merupakan kegiatan investigasi terhadap alam sekitar. IPA merupakan ilmu empirik yang membahas tentang fakta dan gejala alam, maka dalam pembelajarannya harus bersifat faktual, artinya tidak hanya secara verbal sebagaimana terjadi pada pembelajaran secara tradisional.

Semiawan (2008: 104) menyatakan bahwa proses pembelajaran IPA terjadi by doing science di mana siswa yang belajar bukan menjadi spektator, melainkan aktif sejak dini dalam pengalaman nyata. Oleh karena itu, dalam proses pembelajaran IPA harus dirancang menekankan pada pengalaman langsung untuk mengembangkan kompetensi agar peserta didik mampu memahami alam sekitar melalui proses "mencari tahu" dan "berbuat", hal ini akan membantu peserta didik untuk memperoleh pemahaman yang lebih mendalam (Trianto, 2010: 152). Pembelajaran IPA akan lebih bermakna ketika siswa mampu belajar menemukan fakta dan konsep IPA melalui pengalaman nyata. Pemahaman IPA bukan hanya mengetahui fakta-fakta dalam tetapi juga memahami proses IPA, yaitu memahami bagaimana mengumpulkan fakta-fakta dan menghubungkan untuk menginterpretasikannya (Iskandar, 1997: 4).

Pemahaman siswa terhadap konsep-konsep IPA, fenomena, dan peristiwa-peristiwa alam dapat dilihat melalui proses-proses IPA yang dilakukan oleh siswa. Proses-proses IPA yang dilakukan siswa tersebut terdiri dari berbagai keterampilan yang dikenal dengan keterampilan proses sains (Setiawan, 2013). Dengan mengembangkan keterampilanketerampilan proses sains, siswa mampu menemukan dan mengembangkan sendiri fakta dan konsep, serta menumbuhkan dan mengembangkan sikap ilmiah dalam dirinya (Trianto, 2010: 148). Keterampilan proses terdiri dari keterampilan proses dasar dan keterampilan proses terintegrasi (Rosjidan, dkk, 2001: 64).

Hal itu sejalan dengan pendapat Dimyati dan Mudjiono (2006) yang menyatakan bahwa belajar menggunakan pendekatan keterampilan proses memberikan kesempatan kepada siswa untuk belajar mengembangkan keterampilan proses yang dimiliki untuk memahami fakta, konsep, prinsip ilmu pengetahuan. Selain itu, pendekatan keterampilan proses dilaksanakan dengan menekankan pada bagaimana siswa belajar dan bagaimana pula mengelola perolehannya agar menjadi miliknya, sehingga perolehan tersebut dapat dipahami, dimengerti, dan diterapkan sebagai bekal kehidupan di masyarakat sesuai dengan kebutuhannya.

Namun, tidak semua jenis keterampilan proses tersebut dapat dikembangkan untuk semua peserta didik, khususnya di sekolah dasar. Bundu (2006:87) menyatakan bahwa keterampilan proses di SD difokuskan pada keterampilan proses dasar IPA dengan melakukan 
berbagai kegiatan secara mandiri untuk melatih keterampilan proses yang akan dikembangkan. Hal itu karena keterampilan-keterampilan dasar memberikan dasar bagi keterampilan terintegrasi, artinya seberapa baik penguasaan keterampilan-keterampilan terintegrasi akan sangat dipengaruhi oleh penguasaan keterampilan-keterampilan dasar (Suprihadi, dkk, 2000: 155). Indrawati (Trianto, 2010: 144) menyatakan bahwa keterampilan proses dasar meliputi: observasi, klasifikasi, komunikasi, pengukuran, prediksi, dan inferensi.

Tujuan pembelajaran IPA untuk mengembangkan keterampilan proses siwa seperti yang dijelaskan di atas, belum sepenuhnya terlaksana di lapangan. Berdasarkan observasi yang dilakukan 13 Mei 2018 terhadap proses pembelajaran siswa, ditemukan berbagai permasalahan dalam pembelajaran IPA yaitu keterampilan proses IPA siswa cenderung masih belum optimal. Hal ini terlihat selama proses pembelajaran berlangsung masih banyak siswa yang kurang mampu mengamati, mengklasifikasikan, menyimpulkan/menafsirkan, dan juga mengkomunikasikan suatu objek berdasarkan hasil pengamatannya secara detail. Selain itu hampir seluruh siswa tidak dapat memberikan pendapatnya berdasarkan hasil pengamatannya terhadap suatu keadaan.Proses pembelajaran IPA lebih berpusat pada guru. Hal ini terlihat dari aktivitas yang dilakukan guru lebih banyak memberi siswa materi dan kurang melibatkan siswa secara aktif dalam proses pembelajaran. Pembelajaran yang berlangsung lebih banyak menggunakan metode ceramah. Siswa lebih banyak mendengarkan penjelasan guru dan kurang terlibat dalam pembelajaran untuk memperoleh pengetahuan IPA secara mandiri.

Berdasarkan wawancara peneliti dengan guru kelas III SDN 016 Balung pada tanggal 13 Mei 2018, peneliti memperoleh informasi bahwa keterampilan proses dasar IPA siswa kelas III di sekolah tersebut masih tergolong rendah yaitu di buktikan dengan hasil tes tertulis keterampilan proses siswa yang rendah.

Berdasarkan permasalahan yang telah dipaparkan maka saah satu bentuk solusi/ alternative yang dapat digunakan adalah dengan menggunakan model pembelajaran Exampe non Example.

Model pembelajara Example non Example adalah model pembelajaran yang menggunakan media gambar dalam penyampaian materi pembelajaran yang bertujuan mendorong siswa untuk belajar berfikir kritis dengan jalan memecahkan permasalahan-permasalahanyang terkandung dalam contoh-contoh gambar yang disajikan. Dengan penerapan model pembelajaran Example non Example ini, diharapkan keterampilan proses siswa lebih meningkat, ada pelaksanaannya dikondisikan agar semua siswa dapat aktif dan kreatif karena hal ini berpengaruh terhadap keterampilan proses IPA siswa. 
Dengan menggunakan model pembelajaran Example non Example ini peneliti menganggap bisa memberikan jalan keluar terhadap masalah yang dihadapi. Dari fenomena atau gejala-gejala tersebut, terlihat bahwa kurangnya minat belajar siswa terhadap materi pelajaran IPA. Berdasarkan analisa sementara berkemungkinan dipengaruhi oleh strategi yang digunakan guru selama ini, adalah model-model atau metodemetode pembelajaran lama. Oleh karena itu, peneliti akan melakukan perbaikan pembelajaran dengan menerapkan model pembelajaran Example on Example untuk meningkatkan keterampilan proses belajar siswa.

Berdasarkan uraian di atas, maka peneliti melakukan penelitian dengan judul "Penerapan Model Example non Example untuk meningkatkan keterampilan proses sains siswa Sekolah Dasar".

\section{METODE PENELITIAN}

Penelitian yang akan dilaksanakan adalah penelitian tindakan kelas (classroom action research). Aqib (2009:13) mengatakan bahwa penelitian tindakan kelas merupakan suatu pencermatan terhadap kegiatan yang sengaja dimunculkan, dan terjadi dalam sebuah kelas. Tindakan tersebut dilakukan oleh guru, oleh guru bersama-sama dengan peserta didik, atau peserta didik di bawah bimbingan dan arahan guru, dengan maksud untuk memperbaiki dan meningkatkan kualitas pembelajaran (Mulyasa, 2011:11).

Arikunto (2006:60) menyatakan bahwa penelitian tindakan kelas (PTK) adalah penelitian yang dilakukan dikelas dengan tujuan memperbaiki atau meningkatkan mutu praktik pembelajaran Wardani (2002:1.4) menyatakan bahwa penelitian tindakan kelas (PTK) adalah penelitian dilakukan oleh guru didalam kelasnya sendiri melalui refleksi diri dengan tujuan untuk memperbaiki kinerjanya sebagai guru, sehingga keterampilan proses sains siswa meningkat.

Komponen-komponen dalam PTK menurut Arikunto (2010:16)

\section{Perencanaan \\ Rencana tindakan kelas yang dilakukan adalah menyusun Rencana Pelaksanaan Pembelajaran, membuat LKS, merencanakan tes hasil belajar, dan mempersiapakan lembar pengamatan.}

2. Pelaksanaan tindakan

Pelaksanaan dilakukan oleh guru atau peneliti sebagai upaya perbaikan, peningkatan atau perubahan yang diinginkan. Penelitian tindakan kelas dilakukan selama pembelajaran berlangsung.

3. Pengamatan 
Mengamati hasil atau dampak dari tindakan yang dilaksanakan dengan menggunakan lembar observasi. Kegiatan observasi dilaksanakan secara kolaboratif dengan melibatkan teman sejawat untuk mengamati aktifitas guru dan siswa ketika mengikuti pelajaran IPA yang sesuai dengan model pembelajaran Example non Example yang dilakukan dengan lembar observasi. Alat observasi sesuai dengan langkah-langkah pembelajaran.

4. Refleksi

Refleksi meliputi kegiatan menganalisis, manafsirkan, menjelaskan dan menyimpulkan yang dilakukan untuk melanjutkan siklus berikutnya. setelah mengkaji keterampilan proses sains siswa dan hasil pengamatan aktifitas guru, serta menyusuaikan dengan ketercapaian indikator kinerja maka peneliti melanjutkan siklus berikutnya yaitu siklus II untuk mencapai indikator kinerja.

a. Perencanaan (Planning)

Sebelum pelaksanaan tindakan, maka diperlukan perencanaan tindakan. Hal yang ada dalam perencanaan adalah:

1) Peneliti dan guru kelas menetapkan materi yang akan dipelajari dalam pelaksanaan penelitian tindakan kelas.

2) Peneliti dan guru kelas menetapkan waktu pelaksanaan penelitian tindakan kelas.

3) Membuat RPP tentang materi yang akan diajarakan sesuai dengan pendekatan pembelajaran yang digunakan yaitu pendekatan keterampilan proses. RPP ini disusun oleh peneliti dengan pertimbangan dari dosen pembimbing dan guru kelas sebagai pedoman dalam pelaksanaan kegiatan pembelajaran yang akan diobservasi.

4) Menyusun lembar kerja siswa (LKS) kemudian dikonsultasikan dengan dosen pembimbing.

5) Menyusun instrumen penelitian berupa lembar observasi kemudian dikonsultasikan kepada dosen pembimbing. Lembar observasi digunakan sebagai pedoman pengamatan terhadap keterampilan proses sains IPA dan pelaksanaan model pembelajan Example non Example.

b. pelaksanaan (acting)

Pada tahap ini guru melaksanakan kegiatan pembelajaran sesuai dengan rencana sebelumnya yaitu melalui pendekatan keterampilan proses. Selama proses pembelajaran peneliti dibantu oleh pengamat untuk mengamati siswa di kelas. Adapun langkah-langkah pembelajaran melalui pendekatan keterampilan proses yang dilaksanakan oleh guru adalah sebagai berikut.

c. Observasi (Observating) 
Pada tahap ini peneliti melakukan pengamatan terhadap proses kegiatan belajar mengajar menggunakan lembar observasi keterampilan proses dasar IPA siswa, dan lembar observasi keterlaksanaan pendekatan keterampilan proses oleh guru.

d. Refleksi (reflecting)

Pada tahap ini hasil observasi tindakan dari proses pembelajaran yang sudah dilaksanakan kemudian dianalisis dengan berdiskusi antara guru, peneliti, dan rekan-rekan pengamat untuk melihat apakah dalam pembelajaran yang sudah dilaksanakan sudah sesuai dengan rencana dan tujuan pembelajaran atau belum, sehingga dapat dilaksanakan perbaikan dalam siklus selanjutnya. Apabila pada tindakan pertama hasil penelitian masih belum sesuai dengan tujuan yang diharapkan, maka dapat dilakukan perubahan rencana tindakan pada siklus berikutnya. Keputusan untuk menghentikan atau melanjutkan siklus merupakan keputusan bersama antara peneliti dan guru kelas. Siklus dihentikan jika peneliti dan guru kelas sepakat bahwa pembelajaran yang dilakukan sudah sesuai dengan target perbaikan yang telah direncanakan.

\section{Teknik Pengumpulan Data}

\section{Dokumentasi}

Menurut Hermawan (Lestiana, 2017:103) teknik documenter (documentary study) merupakan suatu teknik pengumpulan data dengan menghimpun dan menganalisis dokumen-dokumen, baik dokumen tertulis, gambar maupun elektronik.

Dokumentasi yang digunakan dalam penelitian ini adalah berupa foto-foto atau video-vidio. Dokumentasi digunakan untuk melengkapi data-data secara rinci saat pembelajaran berlangsung, serta ubtuk menguatkan bukti-bukti dan untuk melihat langkah-langkah model Example non Example. Silabus dan RPP.

\section{Observasi}

Observasi adalah cara menghimpun bahan-bahan keterangan yang dilakukan dengan mengadakan pengamatan dan pencatatan secara sistematis terhadap fenomena-fenomena yang sedang dijadikan sasaran pengamatan (Sudijono, 2011: 76-77). Observasi atau pengamatan digunakan sebagai alat penelitian untuk mengukur tingkah laku individu pada saat terjadinya suatu kegiatan pembelajaran yang dapat diamati.Teknik observasi yang digunakan dalam penelitian ini adalah menggunakan observasi partisipatif, dalam observasi ini peneliti terlibat dengan kegiatan guru dan siswa yang digunakan sebagai sumber data penelitian. 
Pengamat yang bertugas mengamati pelaksanaan proses pembelajaran di kelas III SDN 016 Balung yaitu peneliti dan 2 orang rekan peneliti. Hal-hal yang diobservasi meliputi: (1) Aktivitas guru dalam memfasilitasi siswa untuk meningkatkan keterampilan proses sains yang akan diteliti, dan (2) Model Example non Example siswa selama pembelajaran IPA berlangsung yang diamati berdasarkan aktivitas siswa selama mengikuti proses pembelajaran.

\section{Instrumen Penelitian}

Instrumen penelitian merupakan alat atau fasilitas yang digunakan peneliti dalam mengumpulkan data agar pekerjaannya lebih mudah dan hasilnya lebih baik, dalam arti lebih cermat, lengkap dan sistematis sehingga lebih mudah untuk diolah (Arikunto, 2002: 136). Instrumen dalam penelitian ini digunakan untuk mengetahui peningkatan keterampilan proses siswa kelas III SDN 016 Balung pada mata pelajaran IPA dengan menggunakan model Example non Example. Instrumen yang digunakan dalam penelitian ini yaitu berupa lembar observasi dan pedoman wawancara.

\section{Lembar Observasi}

Lembar observasi yang digunakan dalam penelitian ini terdiri dari lembar observasi aktivitas siswa, lembar analisis LKS hasil kerja siswa, dan lembar keterlaksanaan pendekatan keterampilan proses oleh guru.

a. Lembar observasi aktivitas siswa.

Lembar observasi aktivitas siswa merupakan lembar observasi yang digunakan untuk menilai keterampilan proses dasar IPA berdasarkan aktivitas yang dilakukan oleh siswa saat proses pembelajaran berlangsung. Lembar observasi ini diisi oleh pengamat berdasarkan hasil pengamatan terhadap siswa pada saat pembelajaran berlangsung.

b. Lembar keterampilan proses sains

Lembar keterampilan proses sains ini digunakan untuk menilai kemampuan siswa dalam mengamati, mengklasifikasikan, menafsirkan, dan mengkomunikasikan. Adapun penilaian keempat indikator ini dikembangkan dalam bentuk rubrik. Rubrik merupakan panduan penilaian yang menggambarkan criteria yang diinginkan guru dalam menilai atau member tingkatan dari hasil pekerjaan siswa.

\section{Teknik Analisis Data}

Berdasarkan instrument pengumpulan data, ada dua jenis teknik analisis data, yaitu sebagai berikut :

1. Kualitatif

Data kualitatif adalah kalimat-kalimat yang menggambarkan ekspresi siswa tentang pemahaman (koognitif), antusiasnya, kepedan siswa yang dilakrcayaan dirinya, dan motivasinya, Kusnandar (2004:124). Data kualitatif dalam penelitian ini digunakan untuk mendeskripsikan 
proses pembelajaran dengan penrapan model Example non Example yaitu aktivitas guru dan siswa.

Data ini berupa hasil observasi aktivitas guru dan siswa yang dilaksanakan pada setiap siklus, yang mengacu pada setiap kegiatan belajar mengajar melalui model pembelajaran Example non Example. Adapun kegiatan guru yang diamati meliputi kegiatan awal, kegiatan inti, dan kegiatan akhir

2. Kuantitatif

Data kuantitatif dalam penelitin ini diperoleh dari keterampilan proses sains siswa. Setelah data terkumpul melalui lembar observasi, data keterampilan proses siswa diolah dengan menggunakan rumus, yaitu sebagai berikut :

1) Rumus ktuntasan individual

$\mathrm{KBSI}=\underline{\text { Jumlah skor yang dicapai siswa }} \times 100 \%$

$$
\text { Skor Maksimum }
$$

Keterangan:

$\mathrm{KBSI}=$ Ketuntasan belajar siswa secara individual Siswa dikatakan tuntas apabila nilainya lebih tinggi dari KKM yang telah ditetapkanoleh sekolah.

2). Rumus untuk menetukan ketuntasan klasikal $\mathrm{KK}=\frac{\mathrm{JT}}{\mathrm{JS}} \times 100 \%$

Keterangan:

$\mathrm{KK}=$ Ketuntasan Klasikal

$\mathrm{JT}=$ Jumlah siswa yang tuntas

$\mathrm{JS}=$ Jumlah siswa keseluruhan Kriteria ketntasan belajar juga dapat dijadikan criteria keberhasilan. Ketuntasan individu adalah 70 maka ketuntasan klasikal $85 \%$ Mulyasa (syamsurijal, 2017:32). Dengan criteria apabila suatu kelas telah mencapai $85 \%$ dari jumlah yang tuntas maka kelas itu dinyatakan tuntas.

Tabel 3.2

Kategori keterampilan proses sains siswa

\begin{tabular}{|l|l|l|}
\hline NO & Interval\% & Kategori \\
\hline 1 & $85-100$ & Amat Baik \\
\hline 2 & $71-84$ & Baik \\
\hline 3 & $65-70$ & Cukup \\
\hline 4 & $\begin{array}{l}\text { Kurang } \\
\text { dari 65 }\end{array}$ & Kurang \\
\hline
\end{tabular}




\section{HASIL DAN PEMBAHASAN}

\section{A. Deskripsi Hasil Tindakan Tiap Siklus}

Tindakan yang dilakukan pada penelitian ini adalah melaksanakan pembelajaran dengan menerapkan model Example non Example terhadap siswa kelas III SDN 016 Balung. Penelitian ini dilakukan dalam 2 siklus pada mata pelajaran IPA.Siklus I terdiri dari 2 pertemuan dengan tema kesehatan. Proses pembelajaran dilakukan dengan menggunakan model Example non Example. Pada pertemuan disetiap siklus observer mengamati aktivitas guru, aktivitas siswa dan mengisi lembar observasi keterampilan proses sains dengan menggunakan lembaran observasi.

\section{Deskripsi Hasil Tindakan Siklus I}

Pada siklus I terdiri dari 2 pertemuan dengan menyajikan materi disetiap pertemuan dan pemberian LKS disetiap siklus.

\section{a. Perencanaan siklus I}

Pada tahap perencanaan peneliti berdiskusi dengan kepala sekolah dan guru kelas III untuk menetapkan waktu penelitian yaitu pertemuan 1 siklus I dilaksanakan pada tanggal 22 November 2018. Sebelum dilaksanakan tindakan, terdapat beberapa hal yang harus dipersiapkan oleh peneliti yaitu: perangkat pembelajaran terdiri dari silabus, Rencana Pelaksanaan Pembelajaran (RPP), Lembar Kerja Siswa (LKS) dan kunci jawaban yang telah disusun untuk pertemuan 1 siklus I, peneliti sebagai guru untuk mengajar dengan menerapkan Model Example non Example, teman sejawat yaitu Rita sebagai obsever aktivitas siswa, kemudian observer aktivitas guru adalah guru kelas III SDN 016 Balung.

\section{B. Perbandingan Hasil Tindakan Antar Siklus}

Keterampilan proses sains siswa pada siklus pertama hanya mencapai $63,6 \%$ atau keterampilan proses sains siswa pada mata pelajaran IPA tergolong "kurang" karena $63,6 \%$ berada pada rentang $<65 \%$. Artinya keterampilan proses sains siswa pada mata pelajaran IPA belum mencapai $85 \%$ atau berada pada kriteria persentase amat baik. Sedangkan pada siklus II meningkat menjadi 90,9\% atau keterampilan proses sains siswa pada mata pelajaran mata pelajaran IPAtergolong "amat baik" karena 90,9\% berada pada rentang $85-100 \%$. Artinya siswa telah mencapai indikator keberhasilan yang telah ditetapkan, yaitu di atas 85\% atau berada pada kriteria persentase amat baik. Rekapitulasi aktivitas belajar siswa dari siklus I dan siklus II dapat dilihat pada tabel berikut: 
Tabel 4.7

Rekapitulasi Keterampilan Proses Sains Siswa pada Mata Pelajaran IPA, Siklus I dan Siklus II

\begin{tabular}{|c|l|c|c|}
\hline No & \multirow{2}{*}{$\begin{array}{c}\text { Aspek yang } \\
\text { diamati }\end{array}$} & Rata-rata Siklus I & $\begin{array}{c}\text { Rata-rata Siklus } \\
\text { II }\end{array}$ \\
\cline { 3 - 4 } & & Persentase & Persentase \\
\hline 1. & Mengamati & $67 \%$ & $84,1 \%$ \\
\hline 2. & $\begin{array}{l}\text { Mengklasifika } \\
\text { sikan }\end{array}$ & $62,5 \%$ & $81,8 \%$ \\
\hline 3. & $\begin{array}{l}\text { Menyimpulka } \\
\mathrm{n}\end{array}$ & $62,5 \%$ & $80,7 \%$ \\
\hline 4. & $\begin{array}{l}\text { Mengkomuni } \\
\text { kasikan }\end{array}$ & $72 \%$ & $87,5 \%$ \\
\hline \multicolumn{2}{|l}{ Persentase } & $66 \%$ & $83,5 \%$ \\
\hline
\end{tabular}

Dari rekapitulasi yang dipaparkan tabel 4.7, diketahui bahwa persentase keterampilan proses sains siswa pada mata pelajaran IPA pada siklus I yaitu $66 \%$. Selanjutnya rata-rata keterampilan proses sains siswa pada mata pelajaran IPA pada siklus II meningkat menjadi 83,5\%. Selanjutnya peningkatan keterampilan prose sains siswa diketahui bahwa rata-rata siklus I mengamati 67\%, mengklasifikasikan 62,5\%, menyimpulkan $62,5 \%$ dan mengkomunikasikan $72 \%$. Sedangkan siklus II meningkat dari siklus I, rata-rata mengamati $84,1 \%$, mengklasifikasikan $81,8 \%$, menyimpulkan $80,7 \%$ dan mengkomunikasikan $87,5 \%$. Persentase keterampilan proses sains siswa pada mata pelajaran IPA siklus I dan siklus II juga dapat dilihat pada grafik berikut:

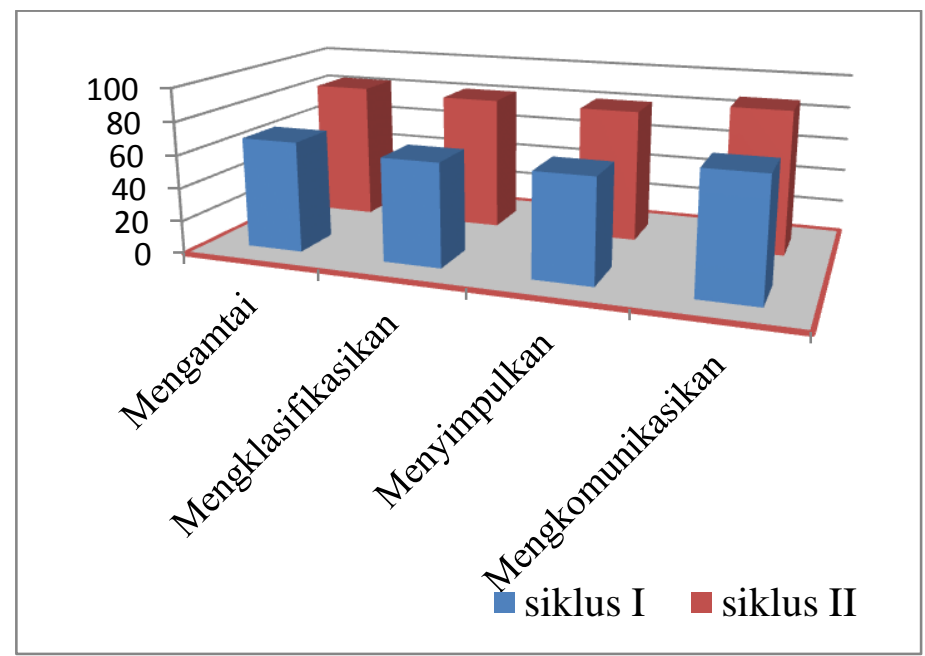

Gambar 4.1 Grafik Perbandingan Keterampilan Proses Sains Siklus I dan Siklus II

Setelah melihat rekapitulasi keterampilan proses sains siswa pada mata pelajaran IPA dan grafik di atas, dapat dilihat bahwa adanya 
peningkatan keterampilan proses sains siswa dari siklus I hingga siklus II. Dapat diketahui bahwa keterampilan proses sains siswa pada siklus II $90,9 \%$ telah mencapai indikator ketuntasan yang telah ditetapkan yaitu 85\% atau berada pada kriteria persentase amat baik. Untuk itu peneliti tidak perlu melakukan siklus berikutnya, karena sudah jelas keterampilan proses sains siswa pada mata pelajaran IPA di kelas III SDN 016 Balung yang diperoleh.

Example non Example adalah model pembelajaran yang menggunakan contoh. Contoh-contoh dapat diperoleh dari kasus atau gambar yang relevan dengan Kompetensi DasarSlavin(Djamarah, 2006:1). Berdasarkan analisis data hasil pelaksanaan tindakan pembelajaran menggunakan model Example non Example pada siswa kelas III SDN 016 Balung dapat disimpulkan telah memenuhi semua aspek indikator keberhasilan. Aspek yang diamati mencakup meningkatnya keterampilan proses sains siswa.Peningkatan keterampilan proses sains siswa dari siklus I sebesar 63,6\%. Jika dilihat dari hasil keterampilan proses sainssiswa pada siklus I keterampilan proses sainssiswa masih tergolong rendah.

Hasil perolehan keterampilan proses sainssiswa pada siklus II mengalami peningkatan jika dibandingkan dengan siklus I. Secara keseluruhan sebesar 90,9\%. Hasil keterampilan proses sainssiswa telah mencapai indikator kebehasilan $85 \%$ atau berada pada kriteria persentase amat baik.Dengan demikian dapat disimpulkan bahwa keterampilan proses sainssiswa mengalami peningkatan dengan menggunakan Model Example non Example. Jadi, hasil analisis ini mendukung hipotesis tindakan yang diajukan yaitu "Jika diterapkan modelExample non Example, maka keterampilan proses sainssiswa pada mata pelajaran IPA di kelas III SDN 016 Balung.

\section{SIMPULAN}

Berdasarkan hasil dan pembahasan, maka dapat disimpulkan: "Melalui penerapan model Example non Example dapat meningkatkan keterampilan proses sains siswa pada mata pelajaran IPA.

1. Dalam upaya meningkatkan keterampilan proses sains dalam perencanaannya guru menyiapkan silabus, rpp, lembar observasi aktivitas guru, lembar observasi aktivitas siswa dan lembar observasi keterampilan proses sains.

2. Pada pelaksanaannya penelitian ini dilakukan atas dua siklus, siklus I dan siklus II dengan empat kali pertemuan, pada pelaksanaannya peneliti menggunakan keterampilan proses sains dengan menggunakan model exsample dan non exsample dengan materi lingkungan sehat dan tidak sehat.

3. Peningkatan keterampilan proses sains siswa pada siklus I adalah $63,6 \%$ dengan kategori kurang, meningkat pada siklus II menjadi 90,9\% dengan kategori amat baik pada siklus II. 
Berdasarkan kesimpulan di atas, berkaitan dengan penerapan model Example non Example telah dilaksanakan, peneliti mengajukan beberapa saran sebagai berikut:

1. Diharapkan guru SDN 016 Balung menggunakan model Example non Example, karena penerapannya dapat meningkatkan keterampilan proses sains siswa.

2. Untuk masa yang akan datang, siswa diharapkan dapat memperhatikan guru menyampaikan materi pelajaran lebih baik lagi, agar apa yang disampaikan guru dapat dimengerti dengan baik.

3. Kepada peneliti selanjutnya sebaiknya meneliti lebih dalam lagi tentang keterampilan proses sains.

\section{DAFTAR PUSTAKA}

Purwanto Ngalim, 2007. Psikologi Pendidikan. Bandung: PT Remaja Rosdakarya.

Slavin, Robert E. 2009. Cooperatif Learning Teori, Riset Praktis. Jakarta:

Sudijono

Anas, 2003. Pengantar Statistik Pendidikan, Jakarta: Raja Grafindo

Persada.

Suwangsih dan Tiurlina. 2006. Model Pembelajaran IPA Bandung: Upi

Press.

Syah Muhibbin, 2010. Psikologi Pendidikan dengan Pendekatan Baru.

Bandung: Remaja Rosdakarya.

Rusdi P. 2007. Metodologi Penelitian. Yogyakarta: Lanarka Pibilisher.

Undang-undang sisdiknas, 2006. Bandung: Fermana.

Lie Anita, 2008. Cooperative Learning. Jakarta: Grasindo.

Nifrida Nia, 2009. Sekitar Pembelajaran Efektif.

http://www.pendis.depag.go.id, 2009 ( diakses tanggal 9 Juli 2011)

Ningsi. 2007. Penulisan Skripsi Penelitian Tindakan Kelas. Pekanbaru.

Pidarta Made, 1990. Perencanaan Pendidikan Parsipatori dengan

Pendekatan Sistem. Jakarta: Bineka Cipta.

Wardani Igak,dkk. 2007. Penelitian Tindakan Kelas. Jakarta: Universitas

Terbuka.

Wina Sanjaya. 2010. Penelitian Tindakan Kelas. Jakarta: Kencana

Winata. 2010. Penulisan Skripsi Penelitian Tindakan Kelas. Tembilahan.

Abdurrahman Mulyono, , 2003. Pendidikan Bagi Anak Berkesulitan

Belajar. Jakarta: Rineka Cipta.

Arikunto Suharsimi Dkk, Penelitian Tindakan Kelas. Jakarta: Bumi Aksara.

Depdiknas. 2006. Kurikulum Tingkat Satuan Pendidikan, Jakarta:

Depdiknas.

Dimyati dan Mudjiono, 1994. Belajar dan Pembelajaran. Jakarta:

Depdikbud.

E. Mulyasa, 2009. Menjadi Guru Profesional. Bandung: Rosda.

Hamalik Oemar, 2003. Kurikulum dan Pembelajaran. Jakarta: bumi Aksra. 
Ibrahim Muslimin, 2000. Pembelajaran Kooperatif. Surabaya: University Press 